\title{
INSTITUTIONAL AND LEGAL PRINCIPLES OF ACTIVITY OF STATE-OWNED ENTERPRISES IN UKRAINE
}

\author{
Victor Koshchynets ${ }^{1}$ \\ National Academy of the Public Prosecutor's Office of Ukraine, Ukraine \\ Olha Zlahoda2 \\ National Academy of Internal Affairs, Ukraine \\ Maryna Haliy ${ }^{3}$ \\ Educational and Scientific Institute No. 1 of \\ National Academy of Internal Affairs, Ukraine
}

\begin{abstract}
The aim of the article is theoretical and methodological research of legal and regulatory framework of activities of state-owned enterprises in Ukraine. The subject of the study is the institutional and legal principles of the activities of state-owned enterprises in Ukraine. Methodology. The research is based on general scientific and special-scientific methods and techniques of scientific knowledge. Analysis and synthesis were used to study the activities of state enterprises as a complex legal phenomenon, to determine their essence and distinguish them from related legal phenomena. The method of the system approach allowed revealing the institutional specificities of the legal framework for the main spheres of state-owned enterprises' activities in Ukraine. Using the formal and legal method, the state of the legal and regulatory framework of the activities of state-owned enterprises in Ukraine was comprehensively examined, as well as its shortcomings, gaps, contradictions, and miscalculations were identified, and recommendations aimed at their elimination were developed. The results of the study revealed that national legislation does not outline exactly the scope of legal activities of state-owned enterprises, but only provides for some of the most important conditions for their operation. In addition, it is scattered covering a considerable body of multi-sectoral legal acts, therefore, it should be optimized and unified, especially in terms of providing the list of general legislative acts on the activities of state-owned enterprises and their management in economic relations. Practical implications. The article defined the correlation of general rules of civil circulation with the special legal acts that regulate the functioning of certain state-owned enterprises with the special purpose and nature of the activity. Relevance/originality. The theoretical and legal study of the institutional and legal principles of the activities of state-owned enterprises in Ukraine consisting of a range of individual normative structures and procedures provides a better understanding of the prospects for the development of national administrative legislation in this sphere.
\end{abstract}

Key words: state-owned enterprises, legal and regulatory framework, state management of economic activity.

JEL Classification: L32, G32

\section{Problem statement}

First, it is necessary to consider the legal principles of the operation of state-owned enterprises, provided for in Articles 64-71, 75, 77 of the Civil Code of Ukraine and Articles 92-95 of the Central Committee of Ukraine. Therefore, based on a joint analysis of these legislative definitions, other normative acts will be considered by dividing into blocks by the logic and general information content, namely: location, vested property, organizational structure, affiliates and representative office, labour collective, management of economic activity, economic relations with other enterprises, organizations, citizens, financial plan, foreign economic

\footnotetext{
Corresponding author:

${ }^{1}$ National Academy of the Public Prosecutor's Office of Ukraine.

E-mail: kvv@ukr.net

${ }^{2}$ Department of Operative and Search Activity, National Academy of Internal Affairs.

E-mail: zlagoda@ukr.net

${ }^{3}$ Department of Legal Documentation, Educational and Scientific Institute No. 1 of National Academy of Internal Affairs.

E-mail: haliy@ukr.net
} 
and other activities of state-owned enterprises, fiscal activity and public procurement.

The location of state-owned enterprises is the actual place of their activities, management, and accounting. Moreover, according to Clause 5, Part 1 of Article 1 of the Law of Ukraine "On State Registration of Legal Entities, Individual Entrepreneurs and Public Formations” (Pro derzhavnu reiestratsiiu yurydychnykh osib, fizychnykh osib-pidpryiemtsiv ta hromadskykh formuvan), the location of a legal entity is the address of the body or persons that, compliant with the constituent documents of a legal entity or law, act on its behalf.

The property of state-owned enterprises is in state ownership and enshrined to it on the right of economic management (state-owned commercial enterprise) or the right of operational management (public enterprise). In addition, the sources of such property are: state property, transferred to the company in accordance with the decision on its establishment; funds and other property earned from the sale of products (works, services) of the enterprise; target funds from the State Budget of Ukraine; bank loans; part of the enterprise's income from economic activity, provided by the charter; other sources not prohibited by law. The general procedure for the management of state property, subjects of management, their rights and responsibilities, and other are provided for by the Law of Ukraine "On Management of Objects of State-Owned Property" (Pro upravlinnia obiektamy derzhavnoi vlasnosti).

Because of independent defining of its organizational structure, a state enterprise can consist of production structural units (manufactories, shops, offices, sections, brigades, offices, laboratories, etc.), as well as functional structural units of the management apparatus (departments, divisions, offices, services, etc.). The specificities of adjusting the organizational structure of the enterprise are in legislative acts such as Laws of Ukraine "On Economic Entities," "On Holding Companies in Ukraine," "On Joint-Stock Companies," and other.

State-owned enterprises have the right to establish subsidiaries, representative offices, divisions, and other separate units. However, according to Part 1 of the Decree of the Cabinet of Ministers of Ukraine No. 24-92 as of December 31, 1992, "On Ordering of Activities of Business Entities Established with the Participation of State-Owned Enterprises" (Pro vporiadkuvannia diialnosti subiektiv pidpryiemnytskoi diialnosti, stvorenykh za uchastiu derzhavnykh pidpryiemstv), state-owned enterprises cannot be founders of enterprises of any organizational forms and types, business associations, cooperatives.

\section{Literature review}

The analysis of scientific literature on the issues of the institutional and legal support of foreign economic activity of industrial enterprises showed that a large number of scientific works by such scientists as O. Amosh, F. Butynets, V. Boiko, P. Haidutskyi, V. Heiets, A. Hradov, S. Demianenko, A. Kandyba, V. Novytskyi, V. Nyzhnyk, V. Okrepilov, I. Piddubnyi, S. Sokolenko, Yu. Tokariev, R. Fatkhutdinov studied the problem under consideration. The aim of the article is theoretical and methodological research of normative and legal regulation of activities of stateowned enterprises in Ukraine.

\section{The main material}

A state-owned enterprise is managed in accordance with its constituent documents based on combined rights of the state regarding the economic use of its property with the participation of the labour collective in the management. The head of an enterprise assumes direct management of economic activities. In the case of hiring, an agreement is concluded with the head of an enterprise. In addition, all economic entities employing hired labour must conclude an agreement between the owner or an authorized body and the labour collective or its authorized body.

The content of an employment and collective agreement and their special conditions, etc. are provided for in Article 21 of the Labour Code of Ukraine (Kodeks zakoniv pro pratsiu Ukrainy). Thus, an employment agreement is an agreement between the employee and the owner of the enterprise, on which the employee undertakes to perform work specified in this agreement, subject to internal labour regulations, and the owner of the enterprise, institution, organization or authorized by him/her body or individual undertakes to pay the employee wages and provide the working conditions necessary for the performance of work, provided for by labour legislation, collective agreement and agreement of the parties. Moreover, the agreement is a special form of the employment agreement, in which terms, rights, duties, and responsibilities of the parties, the terms and conditions of material support and organization of work of the employee, termination of the contract, including pre-term, may be established by agreement between the parties.

In each labour collective, trade unions can be formed in order to represent and protect labour, social, and economic rights and interests of union members (the Law of Ukraine "On Trade Unions, their Rights and Guarantees,” etc.).

State ownership defines the following terms and conditions for the management of an enterprise: must accept and carry out state orders in accordance with the procedure established by the legislation, consider them when forming the production program, determining the prospects of its economic and social development and choosing counteragents; has no 
right to transfer its property to other legal entities or citizens free of charge, except in cases stipulated by law; the State Property Fund of Ukraine is in charge of selling of real estate of an enterprise in accordance with the procedure established by the Cabinet of Ministers of Ukraine (Law of Ukraine "On the State Property Fund of Ukraine"; Order of the State Property Fund of Ukraine No. 1477 of July 30, 1999 "On Approval of Regulations on the Procedure for Alienation of Fixed Assets, which are State-Owned Property," etc.) and others.

It should be noted that, in addition to the general provisions of the economic legislation, the particulars of activities, especially public enterprises, can be found only in the "Model Statute for a Public Enterprise" (Pro typovyi statut kazennoho pidpryiemstva). For example, the juridical status, the legal status of the property, principles of management, the procedure for reorganization and liquidation of an enterprise are defined here.

The main planning document of a state-owned enterprise is the financial plan with approved by the central executive body on economic issues form and methodological recommendations for the development (Order of the Ministry of Economy of Ukraine No. 173 of 21.06.2005 "On approval of the procedure for the formulation, approval and monitoring of the implementation of financial plans for state-owned enterprises, joint-stock companies, holding companies and other economic entities with the statutory fund of more than 50 percent of stateowned shares, and their subsidiaries"; Letter of the Ministry of Economy of Ukraine No. 147-24 / 296 of 01.08.2006 "On filling out the form of the financial plan,” etc.).

According to the financial plan, an enterprise earns income and undertakes expenditures, determines the volume and direction of funds to perform its functions during the year in accordance with the constituent documents. In addition, the amount of funds, transferred to the state as the owner, are approved and credited to the State Budget of Ukraine in the manner prescribed by the Budget Code of Ukraine, etc. After paying mandatory payments, enterprises deduct from the profit remaining at their disposal for the technical re-equipment of production, development of new technologies, environmental protection measures, new construction and working capital (Pro poriadok vykorystannia prybutku derzhavnykh pidpryiemstv, ustanov i orhanizatsii).

State-owned enterprises carry out independently foreign economic activities, which are a part of the foreign economic activity of Ukraine and can open their representative offices, subsidiaries, and production units outside Ukraine. The principles of such activities are provided for in the Law of Ukraine "On Foreign Economic Activity" (Pro zovnishnoekonomichnu diialnist) and exactly Article 4 specifies that the types of foreign economic activity of enterprises include: export and import of goods, capital and labour; international financial transactions and securities transactions; credit and settlement operations; joint business with foreign business entities; organization and implementation of wholesale, consignment and retail trade in Ukraine for foreign currency; commodity exchange operations and other activities, based on forms of counter trade with foreign business entities, etc.

State-owned enterprises pay taxes and state fees on general terms (the Tax Code of Ukraine, Customs Code of Ukraine, Law of Ukraine "On Collection and Accounting of Single Contribution to Obligatory State Social Insurance", etc.), except in cases stipulated by the legislation.

State-owned economic entities must receive all goods (works, services) within public procurement for a calendar year, the procedure and conditions of which are provided for by the Law of Ukraine "On Public Procurement" (Pro publichni zakupivli) under the monitoring of the Ministry of Economic Development and Trade of Ukraine. Moreover, since the activities of state-owned enterprises have a special purpose and nature of activities, they are also regulated with special normative legal acts in addition to general rules of civil circulation. Thus, the latter will be analysed by blocks, classified according to the functioning of the enterprises.

Furthermore, state-owned economic entities have the right to manufacture, store, repair and sell firearms for military purposes, domestic devices for shooting ammunition equipped with rubber bullets and other special devices (Law of Ukraine "On Licensing of Types of Economic Activity" (Pro litsenzuvannia vydiv hospodarskoi diialnosti); Resolution of the Cabinet of Ministers Ukraine "On Approval of the Regulation on Permit System”, etc.).

The Law of Ukraine "On State Defence Order" states that the state defence order is a means of state regulation in the field of scientific and logistical support for the needs of defence and national security of Ukraine, which defines the interaction between ministries, other central and local executive authorities, state institutions, organizations and business entities during its formation, placement and execution, as well as provides measures for the implementation of international treaties of Ukraine on military-technical cooperation.

A state-owned company for the export and import of military and special-purpose products and services (Ukrspecexport) acts as a monopolist in the abovementioned sphere. It is an authorized state mediator in the implementation of foreign economic activities in export and import of military and special-purpose products and services, as well as goods containing 
information constituting State secrets (Resolution of the Cabinet of Ministers of Ukraine "Issues of the state company for the export and import of military and special-purpose products and services", etc.).

The Law of Ukraine "On Licensing of Types of Economic Activities" authorizes the enterprises in case of prior obtaining a license for the development, production, manufacture, storage, transportation, purchase, sale, import into Ukraine, export from Ukraine, use, destruction of narcotic drugs, psychotropic substances and precursors. The indicated actions are subject to strict state control and provide for legal liability (Law of Ukraine "On Narcotic Drugs, Psychotropic Substances and Precursors" (Pro narkotychni zasoby, psykhotropni rechovyny i prekursory), etc.).

Another specific sphere of state activity is the development of medicines. According to Article 3 of the Law of Ukraine "On Medicines" (Pro likarski zasoby), the state policy in development, production, quality control, and sale of drug is aimed at supporting scientific research, development, and implementation of new technologies, as well as production of highly effective and safe medicines, providing the population with the required medicines of proper quality and in a required assortment. Therefore, state-owned enterprises develop medicines following a number of requirements: a pre-clinical study of medicines; clinical trials of medicines; protection of rights of a patient (a volunteer); state registration of medicines.

Activities of state enterprises related to nuclear energy are licensed according to the rules provided for by the Law of Ukraine "On Licensing Activities in the Sphere of Nuclear Energy Use" (Pro dozvilnu diialnist u sferi vykorystannia yadernoi enerhii). In nuclear domestic legislation, a fundamental act is the Law of Ukraine "On the Use of Nuclear Energy and Radiation Safety," which establishes the priority of human and environmental safety, rights and obligations of citizens in nuclear energy use, regulates activities related to the use of nuclear facilities and sources of ionizing radiation, also establishes the legal framework for Ukraine's international obligations regarding the use of nuclear energy.

The Law of Ukraine "On Oil and Gas" (Pro naftu i haz) stipulates the following directions of activity of state enterprises: defines the basic legal, economic, and organizational principles of activity of the oil and gas industry of Ukraine; regulates relations concerning the specifics of the use of oil and gas minerals, extraction, transportation, storage and use of oil, gas and products of their processing to ensure Ukraine's energy security; protects the rights of all subjects of relations arising from the geological study of oil and gas content of the mineral resources.

Moreover, Article 1 of the Law of Ukraine "On Gas (Methane) of Coal Deposits" indicates one more activity in this sphere, that is, the extraction of gas (methane) of coal deposits, which is an economic activity, which includes a set of technical measures aimed at extracting gas (methane) of coal deposits from coal seams, enclosing rocks and underground cavities of operating mines and being prepared for exploitation, and coal deposits not industrially developed, regardless of their further use, as well as spent coal deposits, if the withdrawn gas (methane) is for further use as a material and/or energy resource.

In practice, these regulatory acts are implemented mostly in the activities of the National Joint-Stock Company "Naftogaz of Ukraine" (Resolution of the Cabinet of Ministers of Ukraine "On the Establishment of the National Joint-Stock Company 'Naftogaz of Ukraine”" No. 747 of May 25, 1998).

The State Target Scientific and Technical Space Program of Ukraine for 2008-2012 (Pro zatverdzhennia Zahalnoderzhavnoi tsilovoi naukovotekhnichnoi kosmichnoi prohramy Ukrainy na 2008-2012 roky) is a conceptual document in the sphere of aviation and aerospace construction, under which, in the space sector, state enterprises should carry out: modernization of existing and development of perspective missile carriers, their systems, and also spacecraft; provision of advanced applications in rocket and space technology, devices, ground software and hardware complexes, information technologies; realization of the most relevant and prestigious international research projects and initiatives.

The principles of state-owned enterprises, which carry out extraction and subsequent disposal of minerals, are in the Mineral Resources Code of Ukraine (Kodeks Ukrainy pro nadra), providing for the enterprises: the right to be mineral resources users; types and terms of use of mineral resources; list of rights and duties when using mineral resources; protection of the mineral resources; obligatory permits for the use of mineral resources; features of the design of mining facilities, as well as underground structures; obligatory preservation or liquidation of the enterprise after exhaustion of the mineral resources.

\section{Conclusions}

Therefore, it should be noted that in no case abovementioned normative legal acts outline exactly the scope of legal activities of state-owned enterprises, but only provides for some of the important conditions for their functioning. In addition, it is important that current normative legislation concerning their activities is scattered, covering a considerable body of multi-sectoral legal acts. Therefore, this situation should be optimized and unified, especially in terms of providing the list of general legislative acts on the activities of state-owned enterprises and their management in economic relations. 


\section{References:}

Pro derzhavnu reiestratsiiu yurydychnykh osib, fizychnykh osib-pidpryiemtsiv ta hromadskykh formuvan [On the state registration of legal entities, natural persons-entrepreneurs and public formations] (Law of Ukraine no. 755-IV of May 15, 2003). Vidomosti Verkhovnoi Rady Ukrainy [Bulletin of the Verkhovna Rada of Ukraine]. (2003), 31-32, 263. (in Ukrainian)

Pro upravlinnia obiektamy derzhavnoi vlasnosti [On the management of state-owned entities] (Law of Ukraine no. 185-V of September 21, 2006). Vidomosti Verkhovnoi Rady Ukrainy [Bulletin of the Verkhovna Rada of Ukraine]. (2006), 46, 456. (in Ukrainian)

Pro vporiadkuvannia diialnosti subiektiv pidpryiemnytskoi diialnosti, stvorenykh za uchastiu derzhavnykh pidpryiemstv [On the ordering of the activities of business entities established with the participation of stateowned enterprises] (Decree of the Cabinet of Ministers of Ukraine no. 24-92 of December 31, 1992). Vidomosti Verkhovnoi Rady Ukrainy [Bulletin of the Verkhovna Rada of Ukraine]. (1993), no. 11, 94. (in Ukrainian)

Kodeks zakoniv pro pratsiu Ukrainy [The Code of Labour Laws of Ukraine] (December 10, 1971). Vidomosti Verkhovnoi Rady URSR [Bulletin of the Verkhovna Rada of Ukraine the USSR], supplement to no. 50. (in Ukrainian) Pro typovyi statut kazennoho pidpryiemstva [On the Model Statute of a State-owned Enterprise] (Resolution of the Cabinet of Ministers of Ukraine no. 914 of June 16, 1998). Ofitsiynyi visnyk Ukrainy [Official Bulletin of Ukraine]. (1998), no. 24, 891. (in Ukrainian)

Pro poriadok vykorystannia prybutku derzhavnykh pidpryiemstv, ustanov i orhanizatsii [On the procedure for using the profit of state-owned enterprises, institutions and organizations] (Resolution of the Cabinet of Ministers of Ukraine no. 48-93 of May 10, 1993). Vidomosti Verkhovnoi Rady Ukrainy [Bulletin of the Verkhovna Rada of Ukraine]. (1993), no. 27, 290. (in Ukrainian)

Pro zovnishnoekonomichnu diialnist [On Foreign Economic Activity] (Law of Ukraine no. 959-XII of April 16, 1991). Vidomosti Verkhovnoi Rady Ukrainy [Bulletin of the Verkhovna Rada of Ukraine]. (1991), no. 29, 377. (in Ukrainian) Pro publichni zakupivli [On Public Procurement] (Law of Ukraine no.922-VIII of December 25, 2015). Ofitsiynyi visnyk Ukrainy [Official Bulletin of Ukraine]. (2016), no. 15, 582. (in Ukrainian)

Pro litsenzuvannia vydiv hospodarskoi diialnosti [On Licensing of types of economic activities] (Law of Ukraine no. 222-VIII of 02.03.2015). Vidomosti Verkhovnoi Rady Ukrainy [Bulletin of the Verkhovna Rada of Ukraine]. (2015), no. 23,158 . (in Ukrainian)

Pro narkotychni zasoby, psykhotropni rechovyny i prekursory[On narcotic drugs, psychotropic substances and precursors] (Law of Ukraine no. 60/95-BP of February 15, 1995). Vidomosti Verkhovnoi Rady Ukrainy [Bulletin of the Verkhovna Rada of Ukraine]. (1995), 10, 60. (in Ukrainian)

Pro likarski zasoby [On medicines] (Law of Ukraine no. 123/96-VR of 04.04.1996) Vidomosti Verkhovnoi Rady Ukrainy [Bulletin of the Verkhovna Rada of Ukraine]. (1996), 22, 86. (in Ukrainian)

Pro dozvilnu diialnist u sferi vykorystannia yadernoi enerhii [On permissive activity in the field of nuclear energy use] (Law of Ukraine of January no. 1370-XIV 11, 2000). Vidomosti Verkhovnoi Rady Ukrainy [Bulletin of the Verkhovna Rada of Ukraine]. (2000), 9, 68. (in Ukrainian)

Pro naftu i haz [On oil and gas] (Law of Ukraine no. 2665-III of 12.07.2001). Vidomosti Verkhovnoi Rady Ukrainy [Bulletin of the Verkhovna Rada of Ukraine]. (2001), 50, 262. (in Ukrainian)

Pro zatverdzhennia Zahalnoderzhavnoi tsilovoi naukovo-tekhnichnoi kosmichnoi prohramy Ukrainy na 2008-2012 roky [On the approval of the National state scientific and technical space program of Ukraine for 2008-2012] (Law of Ukraine no. 608-VI of September 30, 2008). Vidomosti Verkhovnoi Rady Ukrainy [Bulletin of the Verkhovna Rada of Ukraine]. (2009), 12, 148. (in Ukrainian)

Kodeks Ukrainy pro nadra [The Mineral Resources Code of Ukraine on]. (July 27, 1994). Vidomosti Verkhovnoi Rady Ukrainy [Bulletin of the Verkhovna Rada of Ukraine]. (1994), 36, 340. (in Ukrainian) 